\title{
Korelasi Total Lymphocyte Count terhadap CD4 pada anak dengan Infeksi Human Immunodeficiency Virus
}

\section{Aulia Fitri Swity, Djatnika Setiabudi, Herry Garna}

Departemen Ilmu Kesehatan Anak Fakultas Kedokteran Universitas Padjadjaran/Rumah Sakit Dr. Hasan Sadikin, Bandung

Latar belakang. Epidemi infeksi human immunodeficiency virus (HIV) merupakan tantangan besar dalam permasalahan kesehatan di dunia. Di Indonesia, jumlah kasus HIV/AIDS anak semakin meningkat tiap tahunnya. Pemantauan jumlah CD4 dapat membantu memutuskan dimulainya pemberian terapi antiretroviral/ARV, tetapi pemeriksaannya mahal dan tidak selalu tersedia di sarana kesehatan. Total lymphocyte count (TLC) diajukan sebagai panduan alternatif selain jumlah CD4 pada keadaan sarana kesehatan yang terbatas.

Tujuan. Menentukan korelasi TLC dengan jumlah CD4, dan menentukan jumlah CD4 berdasarkan pemeriksaan TLC pada anak HIV.

Metode. Penelitian potong lintang berupa observasional analitik, pengambilan data secara retrospektif rekam medis anak HIV yang dirawat inap di Departemen/SMF Ilmu Kesehatan Anak dan rawat jalan di Klinik Teratai Rumah Sakit Dr. Hasan Sadikin, Bandung. Dilakukan analisis regresi linier pada faktor-faktor yang berhubungan bermakna dengan CD4 untuk menentukan korelasi TLC dengan CD4, serta nilai hitung CD4 dari TLC. Kemaknaan ditentukan berdasarkan nilai $\mathrm{p}<0,05$.

Hasil. Subjek penelitian 67 anak HIV, terdiri dari 35 (52\%) laki-laki dan 32 (48\%) perempuan. Rentang jumlah CD4 berkisar antara 6-3.094 $\mathrm{mm}^{3}$, rerata $444,3 \mathrm{~mm}^{3}$ (SD 536,3), median $241 \mathrm{~mm}^{3}$, dan rentang jumlah TLC antara 525-10.738, rerata 3.352,4 (SD 2.020,4), median 2.898. Analisis regresi menunjukkan hubungan linier antara jumlah CD4 sebagai variabel tergantung $(\mathrm{Y})$ dan TLC sebagai variabel bebas (X) menggunakan persamaan $Y=-158,209+0,180 X$. Didapatkan korelasi kuat antara TLC dan jumlah CD4 $(\mathrm{r}=0,68 ; \mathrm{p}<0,001)$.

Kesimpulan. Terdapat hubungan positif antara jumlah limfosit dan jumlah CD4. Jumlah CD4 pada pasien HIV anak dapat diperkirakan dari jumlah limfosit. Diperlukan penelitian lebih lanjut untuk menentukan cut off point TLC dalam inisiasi ARV. Sari Pediatri 2013;15(2):81-6.

Kata kunci: CD4, HIV anak, total lymphocyte count

\footnotetext{
Alamat korespondensi:

Dr. Aulia Fitri Swity (peserta PPDS). Departemen Ilmu Kesehatan Anak Fakultas Kedokteran Universitas Padjadjaran/ RS dr. Hasan Sadikin, Jl. Pasteur 38 Bandung 40163, Telp. (022) 2035957, Fax. (022) 2034426. Email: auliafitri.swity@gmail.com
}

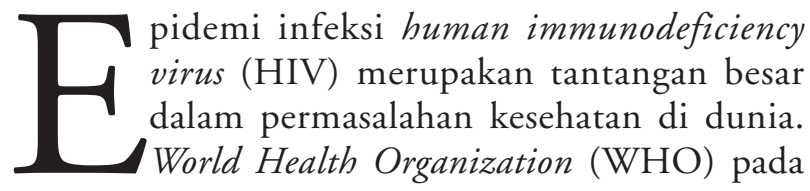


tahun 2009 dinyatakan 33,4 juta orang di dunia hidup dengan HIV, dan 2,1 juta di antaranya adalah anak. ${ }^{1}$ Di Indonesia, terjadi peningkatan kasus HIV dan acquired immune deficiency syndrome (AIDS) setiap tahun. ${ }^{2}$ Data terakhir menunjukkan 2,5 juta jumlah pasien anak berusia kurang dari 15 tahun yang didiagnosis HIV, dan tahun 2007 diperkirakan terdapat 420.000 kasus baru HIV pada anak. ${ }^{3}$

Jika tidak mendapat penanganan yang tepat, sekitar sepertiga anak dengan infeksi HIV akan meninggal dalam tahun-tahun pertama kehidupannya. ${ }^{4}$ Pemantauan jumlah CD4 dapat membantu memutuskan dimulainya pemberian terapi antiretroviral/ ARV, tetapi pemeriksaannya mahal dan tidak selalu tersedia di sarana kesehatan. Jumlah CD4 bervariasi berdasarkan usia, dipengaruhi oleh jenis kelamin, malnutrisi, dan keadaan infeksi..$^{5-7}$ Total lymphocyte count/TLC telah diajukan sebagai panduan alternatif selain CD4 pada keadaan sarana kesehatan yang terbatas. ${ }^{8}$ Penelitian Stebbing dkk, ${ }^{9}$ serta Daka, dan Loha ${ }^{10}$ pada orang dewasa maupun Ashir dkk ${ }^{11}$ pada anak-anak, dinyatakan korelasi yang positif antara TLC dan jumlah CD4. Penelitian yang dilakukan oleh Oetojo ${ }^{12}$ di Bandung-Indonesia, ditunjukkan korelasi yang baik antara jumlah CD4 dan TLC pada orang dewasa.

Tujuan dari penelitian ini adalah menentukan korelasi TLC dengan jumlah CD4, dengan mempertimbangkan faktor lain yang mempengaruhinya, serta menentukan jumlah CD4 berdasarkan pemeriksaan TLC pada anak HIV.

\section{Metode}

Subyek penelitian adalah anak yang didiagnosis terinfeksi HIV, baik yang dirawat inap di Departemen/ SMF Ilmu Kesehatan Anak, maupun pasien rawat jalan di Klinik Teratai Rumah Sakit Dr. Hasan Sadikin Bandung mulai tanggal 1 Januari 2005 sampai dengan 31 Juli 2011. Kriteria inklusi adalah 1) anak terinfeksi HIV pada usia $<14$ tahun, dan 2) pemeriksaan jumlah limfosit dan jumlah CD4 dilakukan pada satu masa perawatan atau kontrol. Kriteria eksklusi adalah 1) anak mengonsumsi obat-obatan steroid jangka panjang dan 2) data tidak lengkap.

Penelitian observasional analitik rancangan potong lintang (cross sectional) dengan data yang diambil secara retrospektif. Berdasarkan tingkat kepercayaan 95\%, power test 95\%, dan koefisien korelasi (r) 0,53 mengacu pada hasil penelitian sebelumnya, didapatkan besar sampel minimal 41 anak. Pemilihan subyek dilakukan dengan metode total sampling pada anak yang memenuhi kriteria inklusi. Data didapatkan dari penelusuran rekam medis pasien anak dengan infeksi HIV yang dirawat inap di Departemen/SMF Ilmu Kesehatan Anak maupun pasien rawat jalan di Klinik Teratai Rumah Sakit Dr. Hasan Sadikin, Bandung. Selanjutnya, dikumpulkan data demografi, hasil pemeriksaan hematologi rutin, dan jumlah CD4 dari pasien yang memenuhi kriteria inklusi penelitian ini.

Secara statistik dilakukan analisis bivariabel untuk menentukan variabel lain yang berhubungan dengan jumlah CD4, yaitu jenis kelamin, status gizi, usia, TLC, Indeks massa tubuh (IMT), kadar hemoglobin, jumlah leukosit, dan jumlah trombosit. Selanjutnya, dilakukan analisis regresi linier berganda (multiple linear regression) pada variabel yang memiliki hubungan bermakna dengan jumlah CD4 (nilai $\mathrm{p}<0,25)$. Persamaan regresi untuk menentukan jumlah CD4 dari TLC ditentukan berdasarkan model akhir. Derajat kekuatan korelasi dinilai, dengan batasan $\mathrm{r}=0,00-0,199$ menunjukkan korelasi sangat lemah, $r=0,20-0,399$ korelasi lemah, $r=0,40-0,599$ korelasi sedang, $r=0,60-0,799$ korelasi kuat, dan $\mathrm{r}=0,80-1,000$ korelasi sangat kuat. Analisis data menggunakan program SPSS for windows versi 17.0. Penelitian mulai dilaksanakan setelah mendapatkan persetujuan Komite Etik Penelitian Kesehatan Fakultas Kedokteran Universitas Padjadjaran RS Dr. Hasan Sadikin, Bandung.

\section{Hasil}

Didapatkan 67 subyek penelitian yang memenuhi kriteria inklusi, terdiri atas 35 laki-laki dan 32 perempuan, dan sisanya dieksklusi karena data tidak lengkap. Selain pemeriksaan jumlah CD4 tidak selalu disertai pemeriksaan hematologi rutin, juga didapatkan pemeriksaan hematologi yang tidak disertai hitung jenis leukosit sehingga nilai TLC tidak dapat dihitung. Karakteristik subyek penelitian seperti usia, jenis kelamin, dan gambaran klinis subyek tertera pada Tabel 1 .

Selanjutnya ditentukan hubungan antara jenis kelamin dan jumlah CD4, hubungan antara status 
Tabel 1. Karakteristik subyek penelitian

\begin{tabular}{|c|c|c|}
\hline Karakteristik & Jumlah & $\%$ \\
\hline \multicolumn{3}{|l|}{ Karakteristik umum } \\
\hline \multicolumn{3}{|l|}{ Jenis kelamin } \\
\hline Laki-laki & 35 & 52 \\
\hline Perempuan & 32 & 48 \\
\hline \multicolumn{3}{|l|}{ Usia (bulan) } \\
\hline$<12$ & 5 & 7 \\
\hline $12-35$ & 20 & 30 \\
\hline $36-59$ & 26 & 39 \\
\hline$>60$ & 16 & 24 \\
\hline \multicolumn{3}{|l|}{ Gambaran klinis } \\
\hline \multicolumn{3}{|l|}{ Status gizi } \\
\hline Normal & 31 & 46 \\
\hline Malnutrisi ringan & 5 & 8 \\
\hline Malnutrisi sedang & 7 & 10 \\
\hline Malnutrisi berat & 24 & 36 \\
\hline \multicolumn{3}{|l|}{ Anamnesis *) } \\
\hline Demam & 31 & 46 \\
\hline Sesak napas & 9 & 13 \\
\hline Penurunan berat badan & 18 & 27 \\
\hline Diare kronik & 26 & 39 \\
\hline Bercak putih di mulut & 17 & 25 \\
\hline Batuk $>3$ minggu & 15 & 22 \\
\hline Berat badan sulit naik & 30 & 45 \\
\hline \multicolumn{3}{|l|}{ Pemeriksaan fisis *) } \\
\hline Hepatomegali & 33 & 51 \\
\hline Splenomegali & 25 & 37 \\
\hline Limfadenopati & 39 & 64 \\
\hline Oral thrush & 22 & 33 \\
\hline
\end{tabular}

gizi dan kelompok usia dengan jumlah CD4, dan korelasi antara TLC, IMT, kadar hemoglobin, jumlah leukosit, dan jumlah trombosit dengan jumlah CD4 (Tabel 2).

Berdasarkan uji biavariabel di atas didapatkan faktor lain yang mempunyai hubungan bermakna dengan jumlah CD4, yaitu jenis kelamin, usia, IMT, kadar hemoglobin, jumlah leukosit, dan TLC. Hubungan bivariabel dengan nilai $\mathrm{p}<0,25$ merupakan kandidat pemodelan analisis regresi linier berganda (multiple linear regression). Model terakhir menunjukkan terdapat korelasi bermakna antara TLC dan jumlah CD4 dengan mempertimbangkan variabel perancu (Tabel 3).

Dari tabel di atas diperoleh persamaan regresi $\mathrm{Y}=$ $-158,209+0,180 \mathrm{X}$, dengan jumlah CD4 sebagai variabel tergantung $(\mathrm{Y})$, dan TLC sebagai variabel bebas (X). Tabel 4 menunjukkan rerata, standar deviasi, nilai tengah dan rentang jumlah dan persentase CD4 serta nilai TLC. Tabel tersebut menunjukkan nilai terendah TLC adalah 525 sehingga persamaan ini dapat digunakan jika nilai TLC lebih atau sama dengan 525.

Total lymphocyte count berkorelasi dengan jumlah CD4 ( $\mathrm{r}=0,68 ; \mathrm{p}<0,001)$ menunjukkan korelasi kuat antara TLC dan jumlah CD4 setelah dikontrol oleh variabel jenis kelamin, usia, IMT, kadar hemoglobin, jumlah leukosit, dan jumlah trombosit.

Keterangan: * Jawaban lebih dari satu

Tabel 2. Hubungan jenis kelamin, status gizi, usia, TLC, IMT, kadar hemoglobin, jumlah leukosit, dan jumlah trombosit dengan jumlah CD4 pasien HIV anak

\begin{tabular}{|c|c|c|c|}
\hline Hubungan & Rerata (SD) & Median (rentang) & $\mathrm{p}$ \\
\hline Jenis kelamin dengan CD4 & & & $0,023^{*}$ \\
\hline Laki-laki & $401,2(621,9)$ & $145(6-3,094)$ & \\
\hline Perempuan & $491,3(428,6)$ & $336,5(21-1,506)$ & \\
\hline Status gizi dengan CD4 & & & $\left.0,306^{* *}\right)$ \\
\hline Normal & $595,16(653,56) 397,40$ & $294,0(6-3,094)$ & \\
\hline Malnutrisi ringan & $(353,16)$ & $192,0(128-972)$ & \\
\hline Malnutrisi sedang & $236,29(156,36)$ & $203,0(51-437)$ & \\
\hline Malnutrisi berat & $319,79(423,77)$ & $216,0(6-1,724)$ & \\
\hline Usia dengan CD4 & & & $\left.0,043^{* *}\right)$ \\
\hline$<12$ bulan & $588(651,08)$ & $395,0(97-1,724)$ & \\
\hline $12-35$ bulan & $497,30(471,71)$ & $273,5(9-1,506)$ & \\
\hline $36-59$ bulan & $226,50(237,97)$ & $137,0(6-841)$ & \\
\hline$\geq 60$ bulan & $686,94(787,74)$ & $348(45-3,094)$ & \\
\hline TLC dengan CD4 & & & $<0,001^{* * *}$ \\
\hline IMT dengan CD4 & & & $0,005^{* * *}$ \\
\hline $\mathrm{Hb}$ dengan CD4 & & & $0,002^{* * *}$ \\
\hline Leukosit dengan CD4 & & & $\left.0,002^{* * *}\right)$ \\
\hline Trombosit dengan CD4 & & & $0,142^{* * *}$ \\
\hline
\end{tabular}


Tabel 3. Hasil analisis regresi hubungan antara TLC dan jumlah CD4 dengan mempertimbangkan variabel perancu

\begin{tabular}{lccc}
\hline Variabel & Koefisien $\beta$ & SE & $\mathrm{p}$ \\
\hline Awal & & & \\
$\quad$ Jenis kelamin & 160,774 & 100,577 & 0,115 \\
Usia & 59,439 & 57,327 & 0,304 \\
IMT & 51,572 & 23,694 & 0,034 \\
Hemoglobin & 39,741 & 28,925 & 0,175 \\
Leukosit & 0,012 & 0,014 & 0,396 \\
Trombosit & 0,000 & 0,000 & 0,459 \\
TLC & 0,144 & 0,030 & $<0,001$ \\
$\quad$ Konstanta & $-1.543,472$ & & \\
Akhir & & & \\
TLC & 0,180 & 0,024 & $<0,001$ \\
$\quad$ Konstanta & $-158,209$ & & \\
\hline
\end{tabular}

Keterangan: Multiple linier regression test metode Stepwise

Tabel 4. Jumlah dan korelasi CD4 dan TLC

\begin{tabular}{lllll}
\hline $\begin{array}{l}\text { Variabel } \\
(\mathrm{n}=67)\end{array}$ & Rerata & SD & Median & Rentang \\
\hline Jumlah CD4 $\left(\mathrm{mm}^{3}\right)$ & 444,3 & 536,3 & 241 & $6-3.094$ \\
Total lymphocyte count $(\mathrm{TLC})$ & $3.352,4$ & $2.020,4$ & 2.898 & $525-10.738$ \\
\hline
\end{tabular}

Korelasi TLC dengan CD4: $\mathrm{r}=0,68(\mathrm{p}<0,001)$

\section{Pembahasan}

Kami mendapatkan korelasi positif antara TLC dan jumlah CD4 dengan $r=0,68$. Korelasi tersebut menunjukkan TLC dapat digunakan sebagai pengganti jumlah CD4 pada keadaan khusus. Dalam perjalanan penyakit HIV, sel limfosit $T$ yang mengekspresikan CD4 sebagai surface marker memegang peran penting dalam regulasi sistem imun, dan merupakan target utama virus HIV. Virus tersebut melekat dan menginfeksi sel CD4, lalu menjadikannya tidak berfungsi. Pada infeksi HIV primer, penurunan jumlah sel T CD4 dalam darah hingga 20\%-40\%. Jumlah CD4 menunjukkan banyaknya sel limfosit $\mathrm{T}$ yang mengekspresikan CD4 dalam sirkulasi darah, sehingga apabila jumlah CD4 menurun maka sel limfosit $T$ pun akan menurun. ${ }^{13,14}$ Penelitian Ashir $\mathrm{dkk}^{11}$ dan Githinji $\mathrm{dkk}^{15}$ menunjukkan korelasi positif antara CD4 dan TLC pada pasien HIV anak, sedangkan Stebbing $\mathrm{dkk}^{9}$ menyatakan dalam keadaan tidak tersedianya fasilitas pemeriksaan jumlah CD4, pemeriksaan TLC dapat digunakan sebagai prediktor CD4 pada pasien dengan infeksi HIV. Hal serupa juga didapatkan oleh Mwamburi $\mathrm{dkk}^{16}$ yang menyatakan TLC cukup baik dalam memprediksi jumlah CD4.

Pemantauan jumlah CD4 dapat membantu memutuskan memulai ARV, beralih pada obat ARV lain, serta menjadi panduan untuk pemberian kotrimoksazol profilaksis. Pada tahun 2006, WHO telah merekomendasikan penggunaan TLC sebagai pengganti jumlah CD4 dalam keputusan pemberian ARV dalam keadaan khusus dengan pertimbangan pemeriksaan TLC lebih banyak tersedia dan mudah dilakukan dibandingkan dengan pemeriksaan jumlah CD $4 .{ }^{\circ}$

Jumlah CD4 dan TLC pada bayi sehat jauh lebih tinggi dibandingkan dengan orang dewasa, dan nilainya menurun sampai mencapai nilai orang dewasa pada usia 6 tahun. ${ }^{5}$ Penelitian Foca dkk $^{17}$ dan Ruel $\mathrm{dkk}^{6}$ menyatakan jumlah CD4 lebih tinggi pada anak perempuan dibandingkan laki-laki, dipengaruhi oleh perbedaan faktor genetik intrinsik antara perempuan dan laki-laki yang tidak terkait dengan kadar hormon seks steroid. ${ }^{6}$ Jumlah CD4 yang rendah berkaitan 
dengan berbagai kondisi seperti infeksi virus, bakteri dan parasit, sepsis, tuberkulosis, trauma, keadaan malnutrisi, serta penggunaan steroid. ${ }^{7}$ Pasien HIV anak dengan status gizi buruk memiliki persentase jumlah CD4 yang rendah dan keadaan tersebut berkaitan dengan angka mortalitas yang tinggi. ${ }^{18}$ Bachou dkk ${ }^{19}$ mendapatkan persentase jumlah sel CD4 yang rendah pada anak HIV dengan malnutrisi berat, mengindikasikan terjadinya imunosupresi selular pada kondisi tersebut, berkaitan dengan deplesi hematologi, serta berbagai bentuk limfosit yang dieksaserbasi oleh infeksi HIV. Dengan demikian, dipikirkan jenis kelamin, usia, dan status gizi sebagai variabel perancu.

Analisis multivariat dalam penelitian menunjukkan bahwa jenis kelamin, usia, IMT, kadar hemoglobin, dan jumlah leukosit tidak berhubungan dengan jumlah CD4. Hal tersebut dapat disebabkan karena pada penelitian terdahulu hanya dilakukan analisis bivariat sehingga tidak menyingkirkan variabel-variabel yang berhubungan lemah dengan jumlah CD 4.,19

Dari penelitian tersebut, diperoleh persamaan regresi dengan jumlah CD4 sebagai variabel tergantung dan TLC sebagai variabel bebas. Dengan demikian, nilai CD4 pada pasien HIV anak dapat diperkirakan dari TLC tanpa memandang jenis kelamin, usia, IMT, maupun parameter hematologi yang lain seperti kadar hemoglobin dan jumlah leukosit. Data penelitian tersebut menunjukkan nilai terendah TLC adalah 525, sehingga persamaan dapat digunakan jika nilai TLC lebih atau sama dengan 525 .

Keterlambatan dalam pemberian ARV dapat menyebabkan kematian pada pasien HIV anak, terutama anak berusia lebih muda yang memiliki progresivitas penyakit yang lebih tinggi. Penundaan pemberian ARV juga berefek negatif pada masa pemulihan sistem imun setelah inisiasi pemberian ARV karena peningkatan jumlah CD4 pada pasien dengan jumlah limfosit yang rendah akan lebih lambat, sehingga memperpanjang periode risiko tinggi terhadap infeksi oportunistik. ${ }^{20}$

Penelitian kami memiliki beberapa keterbatasan, antara lain pengambilan data secara retrospektif menjadikan peneliti tidak dapat mengontrol keadaan dan kualitas pengukuran yang telah dilakukan sebelumnya. Peneliti hanya mengandalkan data sekunder yang telah ada dari catatan rekam medis. Ketidaklengkapan data menjadikan banyak pasien HIV anak yang tidak memenuhi kriteria inklusi sehingga jumlah sampel berkurang. Peneliti juga tidak dapat membandingkan kekuatan korelasi antar kelompok usia maupun menentukan cut-off point TLC dalam inisiasi ARV karena jumlah sampel pada masingmasing kelompok terlalu sedikit.

\section{Kesimpulan}

Disimpulkan bahwa terdapat hubungan positif antara TLC dan jumlah CD4. Jumlah CD4 pada pasien HIV anak dapat diperkirakan dari TLC. Petugas kesehatan setempat dengan sarana kesehatan yang terbatas dapat menentukan jumlah CD4 berdasarkan TLC, sehingga dapat menjadi acuan dalam mendiagnosis HIV, maupun pemantauan anak HIV, dan selanjutnya dapat menentukan inisiasi terapi ARV maupun profilaksis terapi infeksi oportunistik. Diperlukan penelitian lebih lanjut secara prospektif dengan jumlah sampel yang lebih besar untuk menentukan cut-off point TLC dalam inisiasi ARV.

\section{Daftar pustaka}

1. AIDS Epidemic Update. Geneva: United Nations Programme on HIV/AIDS - World Health Organization; 2009.

2. Profil Kesehatan Indonesia 2008. Jakarta: Departemen Kesehatan Republik Indonesia; 2009.

3. Muhaimin T. Epidemiologi dan pencegahan HIV/AIDS di Indonesia. Training HIV-Education Persatuan Dokter Peduli AIDS Indonesia; 2009. Jakarta; 2009.

4. Newell M. Mortality of infected and uninfected infants born to HIV-infected mothers in Africa: a pooled analysis. Lancet 2004;364:9441.

5. Shearer WT, Rosenblatt HM, Gelman RS, Oyomopito R, Plaeger S, Stiehm R, dkk. Lymphocyte subsets in healthy children from birth through 18 years of age: The Pediatric AIDS Clinical Trials Group P1009 Study. J Allergy Clin Immunol 2003;112:973-80.

6. Ruel TD, Zanoni BC, Ssewanyana I, Cao H, Havlir DV, Kamya M, dkk. Sex differences in HIV RNA level and CD4 cell percentage during childhood. Clin Infect Dis 2011;53(6):592-9.

7. Irwin M. Low CD4+ T Lymphocyte counts: a variety of causes and their implications to a multifactorial model of AIDS. 2001 [diunduh 10 Agustus 2011]; Didapat dari: www.virusmyth.com/aids/hiv/milowed4.htm. 
8. WHO. Management of HIV infection and antiretroviral therapy in infants and children: a clinical manual. New Delhi: World Health Organization; 2006.

9. Stebbing J, Sawleshwarkar S, Michailidis C, Jones R, Bower M, Mandalia S, dkk. Assessment of the efficacy of total lymphocyte counts as predictors of AIDS defining infections in HIV-1 infected people. Postgrad Med J 2005;81:586-8.

10. Daka D, Loha E. Relationship between total lymphocyte count (TLC) and CD4 count among peoples living with HIV, Southern Ethiopia: a retrospective evaluation. AIDS Research and Therapy 2008;5:26.

11. Ashir GM, Rabasa AI, Gofama MM, Gimba M, Mshelia LJ. Correlation between CD4 percent and total lymphocyte count (TLC): TLC thresholds are suboptimal for initiation of antiretroviral therapy in HIV-infected Nigerian children. Internet J Infect Dis 2010;9:1-4.

12. Oetojo SH. Pengaruh anemia, neutropenia, dan trombositopenia terhadap korelasi jumlah CD4 dan total lymphocyte count pada penderita HIV/AIDS dewasa [Tesis]. Bandung: Univesitas Padjadjaran; 2009.

13. Burchett SK, Pizzo PA. HIV Infection in infants, children, and adolescents. Pediatr Rev 2003;24:186-94.

14. Laboratory guidelines for enumerating CD4 T lymphocytes in the context of HIV/AIDS. New Delhi: World Health Organization; 2007.
15. Githinji N, Maleche-Obimbo E, Nderitu M, Wamalwa DC, Mbori-Ngacha D. Utility of total lymphocyte count as a surrogate marker for CD4 counts in HIV-1 infected children in Kenya. BMC Infect Dis 2011;11:259.

16. Mwamburi DM, Ghosh M, Fauntleroy J, Gorbach SL, Wanke CA. Predicting CD4 count using total lymphocyte count: A sustainable tool for clinical decisions during HAART use. Am J Trop Med Hyg. 2005;73:58-62.

17. Foca M, Moye J, Chu C, Matthews Y, Rich K, Handelsman E, dkk. Gender differences in lymphocyte populations, plasma HIV RNA levels, and disease progression in a cohort of children born to women infected with HIV. Pediatrics 2006;118:146-56.

18. Fergusson P, Tomkins A, Kerac M. Improving survival of children with severe acute malnutrition in HIV-prevalent settings. Intern Health 2009;1:10-6.

19. Bachou H, Tylleskär T, Downing R, Tumwine JK. Severe malnutrition with and without HIV-1 infection in hospitalised children in Kampala, Uganda: differences in clinical features, haematological findings and CD4+ cell counts. Nutrit J 2006;5:1-7.

20. Kaufmann G, Perrin L, Pantaleo G. CD4 T-lymphocyte recovery in individuals with advanced HIV-1 infection receiving potent antiretroviral therapy for 4 years: the Swiss HIV Cohort Study. Arch Intern Med 2003; 163:2187-95. 